\title{
Effect of ash components and atmospheres on slagging characteristics of high-AAEM lignite gasification
}

\author{
Yanqi Fan ${ }^{l, 2}$, Haixia Zhang ${ }^{l, *}$, Zhiping Zhu ${ }^{l, 2}$, Pengfei Dong ${ }^{l}$, and Qinggang Lyu ${ }^{l, 2}$ \\ ${ }^{1}$ Institute of Engineering Thermophysics, Chinese academy of sciences, Beijing 100190, China \\ ${ }^{2}$ University of Chinese Academy of Sciences, Beijing, China
}

\begin{abstract}
Two kinds of high alkali and alkaline earth metal (AAEM) lignite (TTc and ZDc) were used as fuels, and three atmospheres of $\mathrm{CO}_{2}, \mathrm{CO} / \mathrm{CO}_{2}$, and $\mathrm{H}_{2} \mathrm{O}(\mathrm{g})$ were used in the horizontal tube furnace experiments to simulate the gasification conditions in different parts of the boilers. The relevant thermodynamic calculations on the atmospheres and ash compositions were conducted in FactSage 7.2. The results show that both two coals have a high risk of slagging. Decreasing the relative content of $\mathrm{SiO}_{2}$ or increasing the relative content of $\mathrm{Al}_{2} \mathrm{O}_{3}$ can increase the ash fusion temperatures (AFTs) of TTc; increasing the relative content of $\mathrm{CaO}$ can increase the AFTs of $\mathrm{ZDc}$. Besides, it is not recommended to adjust the relative content of $\mathrm{Fe}_{2} \mathrm{O}_{3}$. The proportion of the liquid phase of $\mathrm{ZDc}$ ash in $\mathrm{CO} / \mathrm{CO}_{2}$ atmosphere is much higher than that of $\mathrm{CO}_{2}$ and $\mathrm{H}_{2} \mathrm{O}(\mathrm{g})$ in a typical circulating fluidized bed $(\mathrm{CFB})$ gasification temperature interval, while the generation of liquid phase of TTc ash is less affected by atmospheres. The bottom of boilers is the most severe slagging zone, and purging with $\mathrm{H}_{2} \mathrm{O}(\mathrm{g})$ is a good way to alleviate the low-temperature slagging of the return feeder.
\end{abstract}

\section{Introduction}

Low-rank lignite is widely distributed in China, the United States, Australia, Indonesia, and Germany, and it plays an integral role in primary energy production and consumption [1]. In China, the excavation and application of the high-AAEM coalfield in the Xinjiang area with a detected reserve of 390 billion tons could ensure the coal demand for the next 100 years [2,3]. AAEMs (mainly referring to $\mathrm{Na}, \mathrm{K}, \mathrm{Ca}$, and $\mathrm{Mg}$ ) in low-rank lignite can act as good catalysts during coal gasification, while, the different migration and transformation characteristics of AAEM elements and complex reactions between AAEMs and other minerals such as $\mathrm{Al}, \mathrm{Si}$, and Fe, will low the AFTs and lead to slagging [1-5].

The CFB gasification technology is extensively applied in the coal chemical process and power generation for their high gas production and low environmental pollution. In the circulation process, coal particles will experience different atmospheric conditions, in which the bottom of the boiler can be approximately regarded as a high concentration $\mathrm{CO}_{2}$ atmosphere, the upper of the boiler as a reducing atmosphere $\left(\mathrm{CO} / \mathrm{CO}_{2}\right)$, and the segment of feeder mainly as $\mathrm{H}_{2} \mathrm{O}(\mathrm{g})$ atmosphere. The migration and transformation of AAEMs and the interactions between different mineral components have certain differences under different atmospheres. Due to the insufficient knowledge of high-AAEM lignite, boilers exhibit a clear incompatibility during the coal utilization process, serious slagging occurred during the gasification process and the normal operation of boilers are affected.
To date, some studies have been conducted on the impact of the equivalence ratio on slagging and fouling characteristics of high-AAEM lignite, there is still lacking a systematic study to explore the influence of gasification agent types in different segments of boilers on slagging and ash fusion characteristics of lignite.

\section{Experimental}

Gasification experiments were conducted in a horizontal tubular furnace. Fig. 1 depicts the schematic diagram of the present experimental system. The system mainly comprises a reactor, gas or water intake system, flow control system, sample injector, and exhaust system. The inside diameter of the alundum-tube reactor is $70 \mathrm{~mm}$, and the length of the constant temperature zone is $150 \mathrm{~mm}$. The maximum working temperature is $1400{ }^{\circ} \mathrm{C}$ with the furnace temperature measured by an S-type thermocouple with an accuracy of $1{ }^{\circ} \mathrm{C}$. The cylinder of $\mathrm{CO}_{2}$ and cylinder containing $60 \% \mathrm{CO}$ in $\mathrm{CO}_{2}$ were used to provide the gas agents (Fig. 1(a)), and the water was introduced to the heating zone of the reactor via a peristaltic pump to provide vapor agent (Fig. 1(b)). In each experiment, 5 $( \pm 0.005) \mathrm{g}$ sample was put in a corundum boat and the corundum boat with the sample was placed in the isothermal zone.

\footnotetext{
* Corresponding author: zhanghaixia@iet.cn
} 

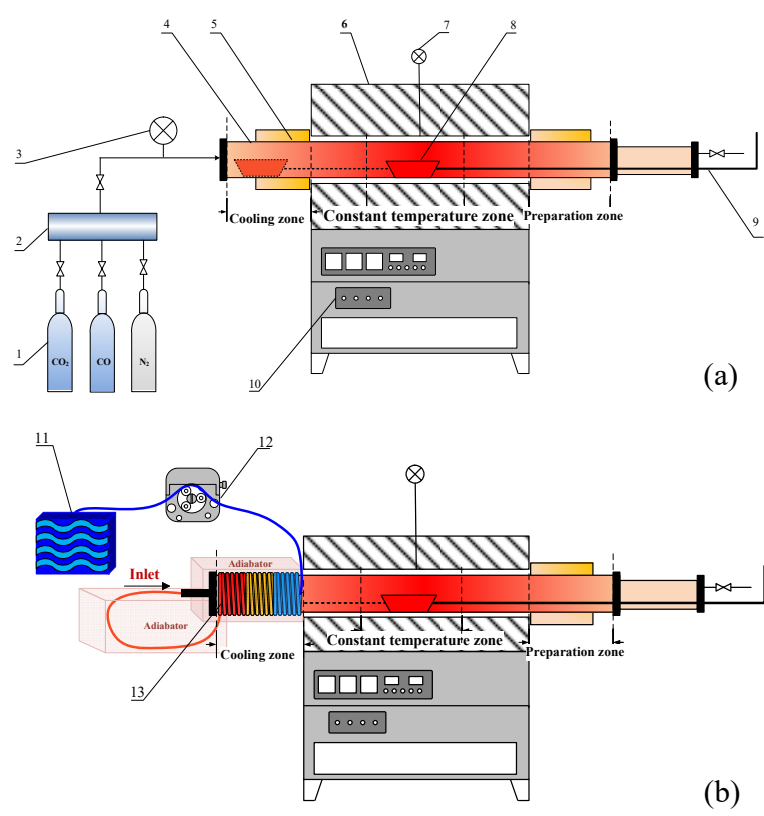

1-gas cylinder group; 2-flow control and distribution system; 3-pressure gauge; 4-tube reactor;5-fixed bracket; 6-electric furnace; 7-thermocouple; 8-corundum boat; 9-pushrod; 10-temperature control system;

11-water tank; 12-peristaltilc pump; 13-heat tracing device

Fig. 1. Schematic diagram of the horizontal tube furnace.

It is noted that the TTc belongs to typical high-sodium coal with $10.58 \% \mathrm{Na}_{2} \mathrm{O}$. ZDc is rich in AAEMs, i.e. $10.95 \% \mathrm{CaO}, 2.72 \% \mathrm{MgO}$, and $7.86 \% \mathrm{Na}_{2} \mathrm{O}$. Besides, the $\mathrm{Fe}_{2} \mathrm{O}_{3}$ content in ash is $18.26 \%$. The coals were milled, air-dried at room temperature, and the size range of $0.18 \sim 0.355 \mathrm{~mm}$ was sieved.

\section{Test Results and Discussions}

\subsection{Influence of typical mineral components on AFTs}

The calculated ternary and pseudo ternary phase diagrams are shown in Fig. 2 and Fig. 3. Percentages of $\mathrm{Al}_{2} \mathrm{O}_{3}, \mathrm{SiO}_{2}$ and $\mathrm{Na}_{2} \mathrm{O}$ and percentages of $\mathrm{Al}_{2} \mathrm{O}_{3}, \mathrm{SiO}_{2}, \mathrm{CaO} / \mathrm{Fe}_{2} \mathrm{O}_{3}$, and $\mathrm{Na}_{2} \mathrm{O}$ of the coal ash samples were normalized to $100 \%$, respectively, and plotted in the corresponding phase diagrams. The line of the same colour are isotherms which illustrate all components that have the same given liquid temperature.

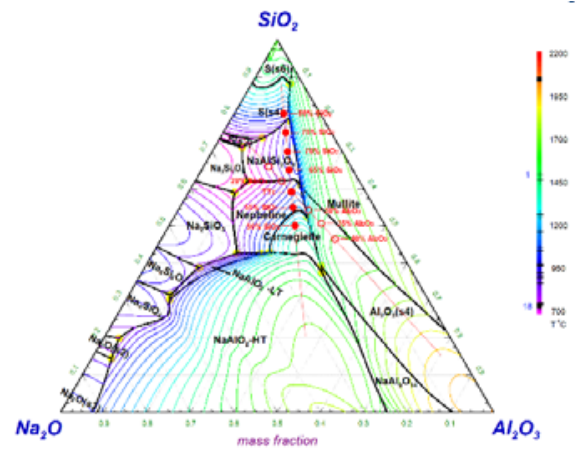

Fig. 2. $\mathrm{SiO}_{2}-\mathrm{Na}_{2} \mathrm{O}-\mathrm{Al}_{2} \mathrm{O}_{3}$ ternary phase diagram of TTc.
TTc ash located in the primary crystallization region of Nepheline that closes to the region of Albite, indicating that a large number of low-temperature eutectic systems could be generated at a relatively low temperature. Reducing the relative content of $\mathrm{SiO}_{2}$ in coal ash will promote the position move toward to the hightemperature melting region of Camegiet, and the risk of slagging of TTc is reduced. It should be mention that the content of $\mathrm{SiO}_{2}$ is suggested to be controlled under $55 \%$. Adjusting the relative content of $\mathrm{Al}_{2} \mathrm{O}_{3}$ in a small range can greatly increase the melting temperature of the entire coal ash. It is believed that increasing the AFTs of coal ash by increasing the relative content of $\mathrm{Al}_{2} \mathrm{O}_{3}$ is better than reducing the $\mathrm{SiO}_{2}$ content.

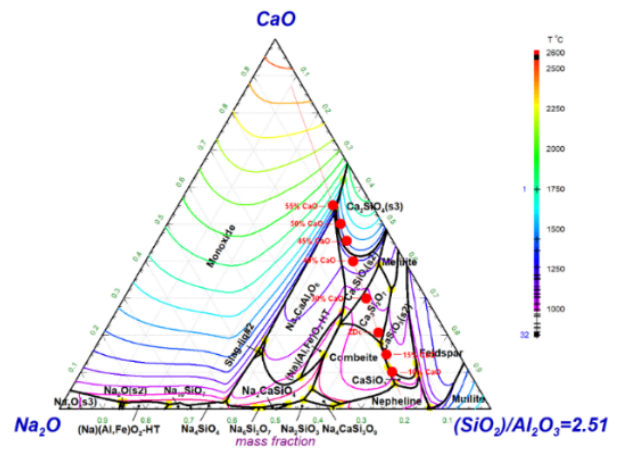

(a) $\mathrm{CaO}-\mathrm{Na}_{2} \mathrm{O}-\left(\mathrm{SiO}_{2}\right) / \mathrm{Al}_{2} \mathrm{O}_{3}$

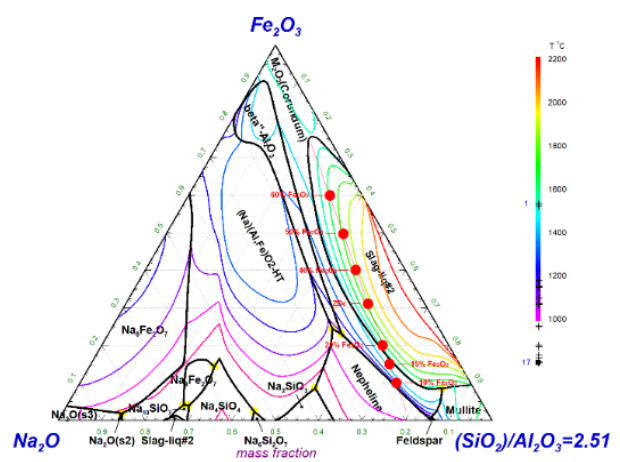

(b) $\mathrm{Fe}_{2} \mathrm{O}_{3}-\mathrm{Na}_{2} \mathrm{O}-\left(\mathrm{SiO}_{2}\right) / \mathrm{Al}_{2} \mathrm{O}_{3}$

Fig. 3. Pseudo ternary phase diagrams of ZDc.

The located position of $\mathrm{ZDc}$ ash in $\mathrm{CaO}-\mathrm{Na}_{2} \mathrm{O}-\mathrm{SiO}_{2}$ $\mathrm{Al}_{2} \mathrm{O}_{3}$ phase diagram is near the junction of $\mathrm{Ca}_{3} \mathrm{Si}_{2} \mathrm{O}_{7}$, $\mathrm{CaSiO}_{3}$, and Combeite with the melting temperature around $1100 \sim 1200{ }^{\circ} \mathrm{C}$. It is found that increasing the relative content of $\mathrm{CaO}$ will increase the melting temperature of $\mathrm{ZDc}$. The located position of $\mathrm{ZDc}$ ash in the $\mathrm{Fe}_{2} \mathrm{O}_{3}-\mathrm{Na}_{2} \mathrm{O}-\mathrm{SiO}_{2}-\mathrm{Al}_{2} \mathrm{O}_{3}$ phase diagram is in the region of the high temperature melting region of Slagliq\#2. Reducing the content of $\mathrm{Fe}_{2} \mathrm{O}_{3}$ in ash will cause a monotonous reduction in melting temperature, however, increasing the content of $\mathrm{Fe}_{2} \mathrm{O}_{3}$ in ash will cause the first increase and then decrease trend of ash melting temperature. It is not recommended for $\mathrm{ZDc}$ to adjust the AFTs by adjusting the relative content of $\mathrm{Fe}_{2} \mathrm{O}_{3}$ in ash.

\subsection{Slagging characteristics under different atmospheres}

As shown in Fig. 4, the slag-liquid formations of mineral compositions were calculated to illustrate the state that the 
input components are completely reacted and the reaction attainment of equilibrium. The liquid phase in ash is comprised of two parts. One is low melting point compounds that are prone to direct melting, and the other is low-temperature eutectics formed by the interactions between the components. The liquid generation tendency of TTc in three atmospheres is basically the same, which indicates that the melting process of TTc ash is less affected by atmospheres. The main substances in ash are Albite $\left(\mathrm{NaAlSi}_{3} \mathrm{O}_{8}\right)$ and Nepheline $\left(\mathrm{NaAlSiO}_{4}\right)$, with the total amount accounts for more than $50 \%$ of the residual ash. The contents of $\mathrm{Ca}$ - or $\mathrm{Fe}$-based components are relatively low. Therefore, the formation of liquid slag under three types of atmospheres is mainly derived from the low-temperature co-melting effect of Nepheline and Albite. A large amount of low-temperature eutectic will increase the ratio of liquid slag in ash rapidly, and the mineral components containing $\mathrm{Ca}$ and $\mathrm{Fe}$ are melted in a short time by the infiltration of the liquid slag.

As for ZDc, FeS has strong fluxing properties, especially when it exists in the form of FeS-FeO (melting point about $940{ }^{\circ} \mathrm{C}$ ) in coal ash. Under the reducing conditions, the overall growth trend of liquid-slag is relatively stable. In the other two atmospheres, Albite and $\mathrm{Na}_{2} \mathrm{SO}_{4}$ in coal ash will melt at about $900{ }^{\circ} \mathrm{C}$, resulting in a large increase in liquid-slag. However, the molten $\mathrm{Na}_{2} \mathrm{SO}_{4}$ will further react with other components to produce other substances with a relatively higher melting point, therefore the proportion of liquid phase in coal ash decreased. It is worth noting that in the typical CFB gasification operation temperature interval, the proportion of liquid phase in a $\mathrm{CO} / \mathrm{CO}_{2}$ atmosphere is much higher than that of $\mathrm{CO}_{2}$ and $\mathrm{H}_{2} \mathrm{O}(\mathrm{g})$, and the growth trend of liquid phase under $\mathrm{H}_{2} \mathrm{O}(\mathrm{g})$ conditions is relatively slow.
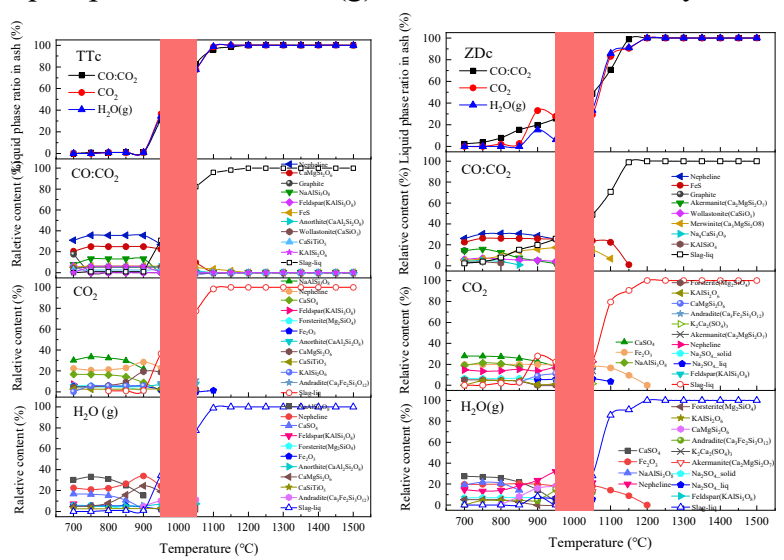

Fig. 4. Slag-liquid formation of TTc and ZDc under different atmospheres.

In summary, the high-AAEM lignite faces the highest risk of slagging under $\mathrm{CO} / \mathrm{CO}_{2}$ atmosphere, and the lowest under $\mathrm{H}_{2} \mathrm{O}(\mathrm{g})$ condition. Combined with the actual operation of the condition of CFB gasification, although the $\mathrm{CO}_{2}$ concentration at the bottom of the furnace is very high, the dense phase zone is still in a reducing atmosphere, therefore it is considered as the most severe slagging segment. As for feeder, it is an advantageous way to alleviate slagging by purging with $\mathrm{H}_{2} \mathrm{O}(\mathrm{g})$.

\subsection{Ash fusion characteristics}

The microstructures and element contents on the surface of different samples are shown in Fig. 5. The surface of TTc gasification particles obtained under $\mathrm{CO}_{2}$ and $\mathrm{CO} / \mathrm{CO}_{2}$ atmosphere have obvious melting areas. From the EDS results, $\mathrm{Na}, \mathrm{Al}$, and $\mathrm{Si}$ are the main enrichment elements of the melting part ( $a, b$, and $c_{1}$ ), and they mainly exist in the forms of sodium silicate and aluminosilicate. The surface of $\mathrm{H}_{2} \mathrm{O}(\mathrm{g})$ particle is rough $\left(\mathrm{c}_{2}\right)$, the main mineral elements on the surface are $\mathrm{Mg}$ and $\mathrm{Ca}$, especially the Ca with content nearly $20 \%$. The contents of $\mathrm{Na}, \mathrm{Al}$, and $\mathrm{Si}$ are relatively low. As for ZDc gasification particles, a large amount of $\mathrm{Fe}$ is enriched on the surface under the $\mathrm{H}_{2} \mathrm{O}(\mathrm{g})$ atmosphere, and the content AAEM metals like $\mathrm{Na}, \mathrm{Mg}$, and $\mathrm{K}$ are at a relatively low level. It is considered that the $\mathrm{H}_{2} \mathrm{O}(\mathrm{g})$ atmosphere will reduce the enrichment of $\mathrm{Na}$ on the surface of the particles, thereby reducing the degree of melting on the surface and reduce the stickiness between the particles.

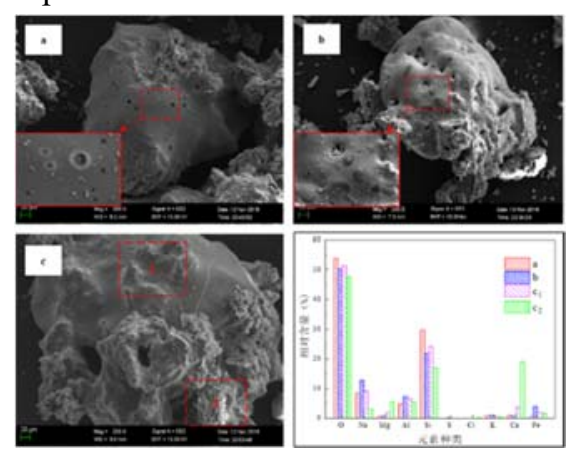

(a) $\mathrm{TTc}$
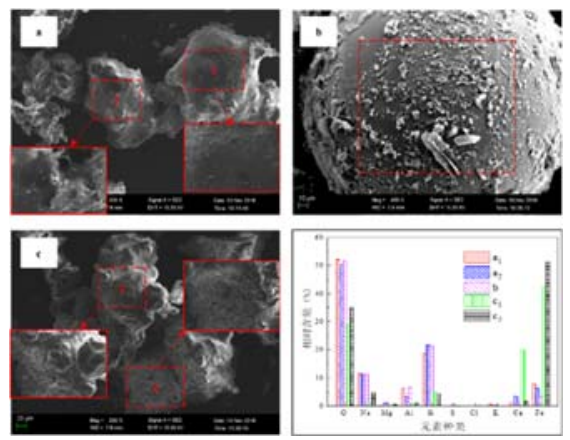

(b) ZDc

Fig. 5. Microstructures and element contents on the surface of gasification particles.

The detected results of XRD displayed in Fig. 6 show that during the gasification process $\mathrm{Na}$-based substances in coal will react with $\mathrm{Al}_{2} \mathrm{O}_{3}$ and $\mathrm{SiO}_{2}$ to generate a large amount of Nepheline. Limited by the reaction rate of the gasification process under the $\mathrm{CO} / \mathrm{CO}_{2}$ atmospheres, there is a certain amount of incompletely reacted coal left on the residues. Therefore, there are strong intensity peaks of $\mathrm{SiO}_{2}$ show in the detection results. A large number of $\mathrm{Fe}_{2} \mathrm{O}_{3}$ peaks are monitored in ZDc residues, which are mainly caused by two reasons. One is the incompletely reacted coal itself contains $\mathrm{Fe}_{2} \mathrm{O}_{3}$, the other is the generated $\mathrm{FeS}$ is re-oxidized during the low-temperature ashing process before the detection. It is worth noting that, the $\mathrm{Ca}$ mainly exists in the form of $\mathrm{Ca}_{2} \mathrm{Al}_{2} \mathrm{SiO}_{7}$ in $\mathrm{CO}_{2}$ 
atmosphere and in the form of $\mathrm{CaO}$ in $\mathrm{H}_{2} \mathrm{O}(\mathrm{g})$ condition, which indicates a higher potential of slagging in $\mathrm{CO}_{2}$ atmosphere.
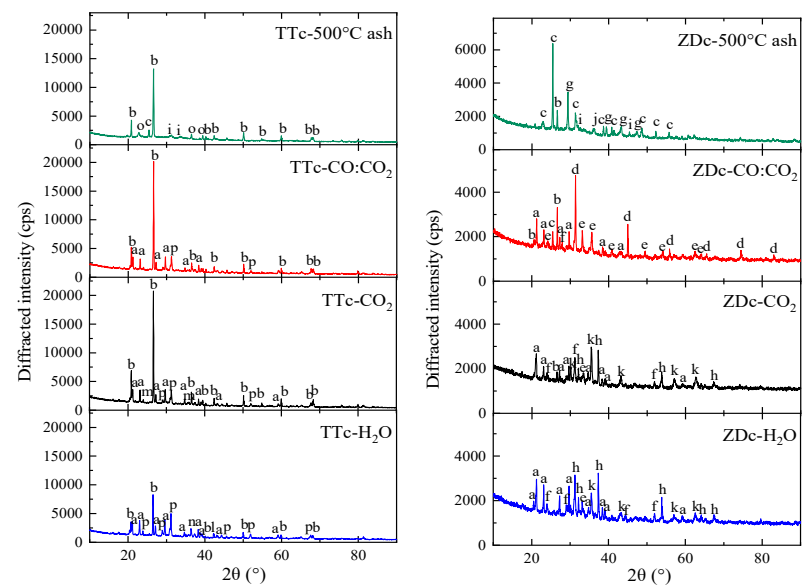

a-K $(\mathrm{Na}, \mathrm{K})_{3} \mathrm{Al}_{4} \mathrm{Si}_{4} \mathrm{O}_{16} ; \mathrm{b}-\mathrm{SiO}_{2} ; \mathrm{c}-\mathrm{CaSO}_{4} ; \mathrm{d}-\mathrm{NaCl}$; e- $\mathrm{Fe}_{2} \mathrm{O}_{3} ; \mathrm{f}-\mathrm{Ca}_{2} \mathrm{Al}_{2} \mathrm{SiO}_{7} ; \mathrm{g}-\mathrm{CaCO}_{3} ; \mathrm{h}-\mathrm{CaO} ; \mathrm{i}-\mathrm{Na}_{2} \mathrm{SO}_{4}$; j- $\mathrm{Na}_{7} \mathrm{Al}_{3} \mathrm{O}_{8} ; \mathrm{k}-\mathrm{Fe}_{2} \mathrm{MgO}_{4} ; \mathrm{l}-\mathrm{FeO} ; \mathrm{m}-\mathrm{KAlSi}_{3} \mathrm{O}_{8} ; \mathrm{n}-\mathrm{Fe}_{2} \mathrm{Al}_{2} \mathrm{O}_{4}$; o-( $\mathrm{Mg}, \mathrm{Fe})_{2} \mathrm{SiO}_{4} ; \mathrm{p}-\mathrm{Ca}_{2} \mathrm{MgSi}_{2} \mathrm{O}_{7}$

Fig. 6. Crystal phase of samples.

Fig. 7 shows the relationship between the softening temperature $(\mathrm{ST})$ and the retention ratio of sodium $\left(\mathrm{R}_{\mathrm{Na}}\right)$, where the $\mathrm{R}_{\mathrm{Na}}$ is defined as the ratio of the sodium content in the gasification residues to the content in the raw coal [6], which can be calculated by the following equation:

$$
R_{N a}=\frac{O V_{\text {residue }} \times A \times C}{O V_{\text {coal }}} \times 100 \%
$$

Where $O V_{\text {residue }}$ and $O V_{\text {coal }}$ represent the original value of sodium in gasification residues $\left(\mathrm{mg} \cdot \mathrm{g}^{-1}\right)$ and raw coal, respectively, $A$ is the ash ratio $(\%)$, and $C$ is the gasification residue ratio $(\%)$.

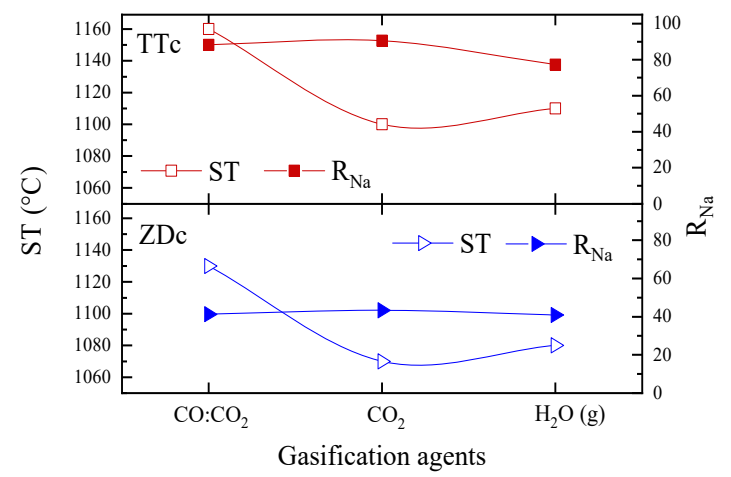

Fig. 7. Relationship between $\mathrm{R}_{\mathrm{Na}}$ and $\mathrm{ST}$ under different atmospheres.

The $\mathrm{R}_{\mathrm{Na}}$ of gasification residues under $\mathrm{H}_{2} \mathrm{O}(\mathrm{g})$ condition is the lowest, which proves that the $\mathrm{H}_{2} \mathrm{O}(\mathrm{g})$ atmosphere can indeed promote the release of $\mathrm{Na}$ during the gasification process. The $\mathrm{R}_{\mathrm{Na}}$ under $\mathrm{CO}_{2}$ and $\mathrm{CO} / \mathrm{CO}_{2}$ atmosphere are both at a relatively high level. However, the reasons for the high $\mathrm{R}_{\mathrm{Na}}$ in the two types of gasification residues are different. Under $\mathrm{CO}_{2}$ conditions, the Na-based components react with other mineral components to form silicate and aluminosilicate and be retained in the gasification residues, while under $\mathrm{CO} / \mathrm{CO}_{2}$ conditions, a certain amount of $\mathrm{Na}$ in the gasification residues is derived from the unreacted sample. Therefore, the existence forms and characteristics of $\mathrm{Na}$ under the two conditions are different. Besides, the refractory framework structure formed by carbon crystals in the residues greatly improves the AFTs of the entire gasified ash. Therefore, although the $\mathrm{R}_{\mathrm{Na}}$ is high, the gasification residues still exhibit high melting properties in $\mathrm{CO} / \mathrm{CO}_{2}$ atmosphere.

\section{Conclusion}

Based on the results and discussions presented above, the conclusions are obtained as below:

(1) For TTc, increasing the AFTs by increasing the relative content of $\mathrm{Al}_{2} \mathrm{O}_{3}$ is better than reducing the $\mathrm{SiO}_{2}$ content. For ZDc, increasing the content of $\mathrm{CaO}$ in ash will increase the AFTs, and it is not recommended to adjust the AFTs by adjusting the relative content of $\mathrm{Fe}_{2} \mathrm{O}_{3}$ in ash.

(2) The melting process of TTc ash is less affected by atmospheres. As for $\mathrm{ZDc}$, the proportion of the liquid phase in a $\mathrm{CO} / \mathrm{CO}_{2}$ atmosphere is much higher than that of $\mathrm{CO}_{2}$ and $\mathrm{H}_{2} \mathrm{O}(\mathrm{g})$ in the typical CFB gasification operation temperature interval.

(3) $\mathrm{The} \mathrm{H}_{2} \mathrm{O}(\mathrm{g})$ atmosphere can promote the release of $\mathrm{Na}$ during the gasification process, and alleviate slagging. The dense phase zone in the bottom is considered the most severe slagging segment. As for the return feeder, it is an advantageous way to alleviate slagging by purging with water vapor.

\section{Acknowledgement}

This work was funded by Beijing Municipal Science and Technology Commission (No. Z181100005118006).

\section{References}

1. YQ Fan, HX Zhang, QG Lyu. Fuel, 267 (2020)

2. GL Song, XB Qi, WJ Song. E\&F, 30, 5 (2016)

3. Duchesne MA, Hughes RW, Lu DY. FPT, 125, 1833 (2014)

4. Kurowski MP, Spliethoff H. FPT, 152 (2016)

5. Ilyushechkin AY, Roberts D. FPT, 147,47-56 (2016)

6. HX Zhang, XW Guo, ZP Zhu. Fuel, 189, 301-311 (2017) 